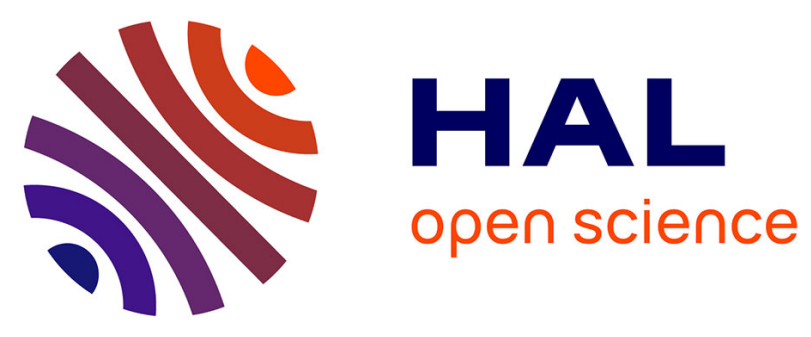

\title{
Rapid diagnosis of Clostridium difficile infection by multiplex real-time PCR.
}

\author{
Frédéric Barbut, Marc Monot, Antoine Rousseau, Sébastien Cavelot, \\ Tabassome Simon, Béatrice Burghoffer, Valérie Lalande, Jacques Tankovic, \\ Jean-Claude Petit, Bruno Dupuy, et al.
}

\section{To cite this version:}

Frédéric Barbut, Marc Monot, Antoine Rousseau, Sébastien Cavelot, Tabassome Simon, et al.. Rapid diagnosis of Clostridium difficile infection by multiplex real-time PCR.: Diagnosis of Clostridium difficile Infection and Identification of the Epidemic clone 027 by Multiplex Real-Time PCR. (Titre fichier auteur). European Journal of Clinical Microbiology and Infectious Diseases, 2011, 30 (10), pp.1279-85. 10.1007/s10096-011-1224-z . pasteur-01370849

\section{HAL Id: pasteur-01370849}

\section{https://hal-pasteur.archives-ouvertes.fr/pasteur-01370849}

Submitted on 23 Sep 2016

HAL is a multi-disciplinary open access archive for the deposit and dissemination of scientific research documents, whether they are published or not. The documents may come from teaching and research institutions in France or abroad, or from public or private research centers.
L'archive ouverte pluridisciplinaire HAL, est destinée au dépôt et à la diffusion de documents scientifiques de niveau recherche, publiés ou non, émanant des établissements d'enseignement et de recherche français ou étrangers, des laboratoires publics ou privés.

\section{(1) $(1) \Theta$}

Distributed under a Creative Commons Attribution - NonCommercial - NoDerivatives| 4.0 
4 Frédéric Barbut $^{1^{*}}$, Marc Monot ${ }^{2 *}$, Alexandra Rousseau ${ }^{3}$, Sébastien Cavelot $^{1}$, Tabassome

5 Simon $^{3}$, Béatrice Burghoffer ${ }^{1}$, Valérie Lalande ${ }^{1}$, Jacques Tankovic ${ }^{1}$, Jean-Claude Petit ${ }^{1}$,

6 Bruno Dupuy ${ }^{2}$ and C. Eckert ${ }^{1}$

$7 \quad{ }^{1}$ National Reference Laboratory for $C$. difficile, Paris VI University, Paris, France

$8 \quad 2$ laboratoire Pathogénèse des bactéries anaérobies, Institut Pasteur, Paris, France

$9{ }^{3}$ Clinical Research Unit, Department of Pharmacology, Assistance Publique-Hôpitaux de

10 Paris, Saint-Antoine hospital, Paris VI University, Paris, France

11 "These authors contributed equally to this work.

12

13 Corresponding author:

14 Frédéric Barbut

15 Hôpital Saint-Antoine

16 UHLIN

17184 rue du faubourg Saint-Antoine

1875012 Paris

19 France

$20 \quad$ tel : +33149283008

21 fax : +33149283009

22 mail : frederic.barbut@ sat.aphp.fr

24 Short title : C. difficile toxin B detection by real-time PCR

25 Key words : Clostridium difficile, diagnostics, real-time PCR, toxins 
2 Abstract

3 Rapid detection of toxigenic Clostridium difficile strains is crucial for optimal management of

4 patient with $C$. difficile infection (CDI). Currently, the «gold standards » for the diagnosis of 5 CDI are the cytotoxicity assay and the toxigenic culture. However both methods are time 6 consuming and results are not available before 24-48 hours. The objectives were to develop 7 and evaluate a multiplex in-house real-time PCR for the simultaneous detection of toxigenic strains of $C$. difficile and the presumptive identification of the epidemic NAP1/027/BI strain

9 from stools. Genomic DNA was extracted from stools using the NucliSENS miniMAG Platform (bioMérieux, La Balme-les-Grottes, France). Amplifications were performed using 11 specific primers for $t c d B$ and $t c d C$ on ABI Prism 7300 (Applied Biosystem). Detection of amplicons was done using TaqMan probes. Analytical sensitivity of the multiplex real-time PCR for detecting $t c d B$ was estimated to $10 \mathrm{UFC/g}$ of stools. This assay was assessed from 881 consecutive unformed stools from patients suspected of having CDI. The gold standard was the toxigenic culture for the diagnosis of CDI, and PCR ribotyping for the identification of the NAP1/027/BI strain. The prevalence of positive toxigenic culture was $9.31 \%$. Compared to the toxigenic culture, the sensitivity, specificity, positive and negative predictive values were $86.59 \%, 97.43 \%, 78.02 \%$ and $98.57 \%$ for the real-time PCR and $70.73 \%, 100 \%$, $100 \%$ and $97.08 \%$ for the cytotoxicity assay. The epidemic clone NAP1/027/BI was neither detected by real-time PCR nor by the gold standard assay.

These results indicated that our in-house real-time PCR assay was more rapid and sensitive than the cytotoxicity assay for the detection of toxigenic $C$. difficile from stool samples. 


\section{INTRODUCTION}

3 Clostridium difficile is currently responsible for 10 to $25 \%$ of cases of antibiotic-associated

4 diarrhea and for virtually all cases of pseudomembranous colitis (PMC)(7, 20, 23). This spore

5 forming bacterium has also emerged as the leading infectious cause of healthcare-associated

6 diarrhea in adult patients. The epidemiology of $C$. difficile infections (CDI) has dramatically

7 changed over the last decade $(3,13,18,39)$. Infections have been reported more frequent and more severe both in North America and Europe $(6,24,28,30)$. This trend is assumed to be due in part to the rapid emergence and spread of a specific hypervirulent clone of $C$. difficile belonging to PCR ribotype 027 (also characterized as toxinotype III, North America PFGE pulsotype 1 [NAP1] and restriction endonuclease analysis group BI). This clone has been shown to overproduce in vitro both toxins $\mathrm{A}$ and $\mathrm{B}$. The overproduction was suggested to be related to the absence of functional TcdC, the negative regulator of toxin gene expression (27) by a single nucleotide deletion at position 117 in TcdC encoding gene (42). The NAP1/027/BI strain also produces a third toxin (binary toxin) and high quantity of spores, which disseminate easily in the hospital environment $(2,29)$.

Prompt diagnosis of CDI is essential not only for patient management but also for swift implementation of control measures. Historically, the cytotoxicity assay has been considered as the «gold standard» for the diagnosis of $C$. difficile infections (11). However this method

21 is time consuming, needs an incubation of at least $24 \mathrm{~h}$, and requires cell culture facilities. More recently, the toxigenic culture has been re-accepted as a gold standard $(14,15)$. But again, this technique is too long to be clinically useful. As of today, most laboratories have adopted enzyme immunoassays for toxins A and B in routine (5). These assays are easier to perform, more rapid and do not require specific technical skill. However they are not sensitive 
1 enough to be used as a stand-alone test for $C$. difficile diagnosis $(14,15,17,32)$. More

2 recently, real-time PCR assays have been developed in order to overcome the lack of

3 sensitivity of EIAs and to reduce the time of culture. These assays include in-house real-time

$4 \quad$ PCR as well as Food and Drug Administration (FDA)-cleared commercial assays. Numerous

5 clinical studies have shown that these assays exhibit the best concordance with the results of

6 toxigenic culture as compared to enzyme immunoassays and could represent therefore a

7 promising alternative for the diagnosis of CDI (17, 22, 25, 31, 35-38).

8 The purpose of this study was to develop and to evaluate a multiplex real-time PCR for both

9 the detection of toxigenic $C$. difficile strains from stools and the presumptive identification of NAP1/027/BI strain.

11 (This work was presented at the 50th ICAAC meeting, Boston, 12 to 15 September 2010).

12

13

14

15

16

17

18

\section{MATERIALS AND METHODS}

\section{Bacterial strains}

Bacterial strains were obtained from the national reference laboratory for $C$. difficile (Paris, France), from the Pasteur Institute (B. Dupuy, laboratoire Pathogénèse des bactéries anaérobies) and from Hines VA (S. Sambol, Hines, Illinois, USA). Sixty eight C. difficile strains were studied for the development of the real-time PCR including one non toxigenic strains (ATCC 43597), and 67 toxigenic strains from toxinotype $0 \quad(n=10$ including VPI 10463), I ( $\mathrm{n}=1)$, III ( $\mathrm{n}=32$ including CIP 107932), IV ( $\mathrm{n}=4$ including CIP 109239), V ( $\mathrm{n}=4$ including CIP109238), VI ( $n=5)$, VII ( $n=1)$, VIII (n=3), IX (n=1), XII ( $n=3)$, XIV (n-=1), XX $(n=1), \operatorname{XXIV}(n=1)$. All strains from toxinotype III were characterized by PCR-ribotyping and tcdC sequencing. The analytical specificity of the assay was tested using 8 Clostridium spp. 
1 other than C. difficile: C. bifermentans (ATCC 638), C. amygdalinum (gift from MR Popoff,

2 Institut Pasteur), C. innocuum (NCIB 10674), C. ramosum (ATCC 25582), C. sordellii (NCIB

3 10717), C. perfringens (CIP 103409), C. tertium (ATCC 14573) and C. sphenoides (ATCC

4 19403). DNA from strains was extracted with the Instagene Matrix kit (Bio-Rad, Ivry, 5 France), as previously described (6).

\section{$7 \quad$ Study population and sample collection}

8 This prospective study was approved by the Comité de Protection des Personnes from SaintAntoine Hospital and by the Commission Nationale de l'Informatique et des Libertés (CNIL $\mathrm{N}^{\circ}$ 1193577). Eligible patients included those with a suspected CDI for whom unformed stools specimens were submitted by physicians to the laboratory for $C$. difficile testing. Duplicate specimens (defined by stools samples from the same patient within a period of 10 days) and specimens from patients under 18 years of age were excluded.

Eight hundred and eighty one consecutive diarrheal stool samples (stools taking the shape of the container) were collected from May 2008 to February 2009 from patients hospitalized in four different university-affiliated hospitals in Paris (Tenon hospital, $\mathrm{n}=44$; Saint-Antoine hospital, n=392 ; Pitié-Salpêtrière hospital, n=287) and surrounding (C. Foix/J. Rostang hospital, $\mathrm{n}=158$ ). Stool samples were stored at $+4^{\circ} \mathrm{C}$ until processing and analysis were done within $48 \mathrm{~h}$ of collection. Specimens were homogenized and then split: a portion of the specimen was used to test for PCR, culture and cytotoxicity assay. The remaining unformed stool was frozen at $-80^{\circ} \mathrm{C}$ for subsequent controls. Additionally, five frozen stools from patients having a documented CDI due to 027 strain were also investigated (obtained from J.P. Canonne, Hôpital de Lens, France). 
1 DNA extraction was performed using the NucliSENS miniMAG Platform (bioMérieux, La

2 Balme-les-Grottes, France) according to the manufacturer's instructions. Stools were diluted

3 1:20 in sterile PBS and homogenized. Two hundred microliters of this dilution were mixed

4 with $2 \mathrm{ml}$ of Nuclisens Lysis Buffer and $5 \mu \mathrm{l}$ of rv3865-containing plasmid $(0,03 \mathrm{ng} / \mu \mathrm{l})$. The

5 nucleic acid extraction method was based on high-affinity magnetic silica particles. Briefly,

6 under high salt conditions, nucleic acid binds to the silica particles. These silica particles act

7 as a solid phase and non-nucleic acid components are removed by several washing steps

8 performed in the NucliSens miniMAG disposable plastic tray. Finally, nucleic acids are eluted

9 from the solid phase and the eluate is stored at $+4{ }^{\circ} \mathrm{C}$ until use.

10

11 Real-time PCR

12 Amplifications were performed either from purified genomic DNA or from crude DNA extracted from feces samples. A multiplex real-time PCR was developed for the simultaneous detection of the $t c d B$ gene, the deletion at position 117 of $t c d C$ gene and a DNA internal control. The internal control consisted of a plasmid containing part of the gene rv3865 from Mycobacterium tuberculosis (19). The internal control was added on initial processing of DNA extraction of stool samples. It acts as control of the general process (including DNA extraction step) and monitors the presence of PCR inhibitors. Primers and probes used in the assay are described in table 1 . Primers and probes for $t c d B$ were designed from the non repeat region of the known $t c d B$ sequence (accession number $n^{\circ}$ NC_009089) using the Primer 3 software (http://frodo.wi.mit.edu/primer3/).

Amplification was performed in a 96-well PCR plate in the ABI Prism 7300 real-time PCR instrument (Applied Biosystems, Roche). A final volume of $20 \mu 1$ was used containing $2 \mu 1$ of extracted DNA, $10 \mu 1$ of TaqMan Master Mix (Roche, Minneapolis), $2 \mu 1$ Mix containing Primers $(200 \mathrm{nM}$ of each primers except for reference primers $(20 \mathrm{nM})), 2 \mu 1$ Mix containing 
1 probes (100 $\mathrm{nM}$ of each probes) and water. The reaction was subjected to denaturation at

$295^{\circ} \mathrm{C}$ for 2 min followed by 40 cycles of denaturation at $95^{\circ} \mathrm{C}$ for $45 \mathrm{~s}$, annealing/elongation

3 at $60^{\circ} \mathrm{C}$ for $1 \mathrm{~min}$. Samples were tested in triplicate and negative and positive controls were

4 included with each run. The positive control was DNA purified from 027/NAP1/BI strain and

5 the negative control was water. Fluorescent signal was measured at the end of the

6 annealing/elongation step in each cycle. In case of indeterminate results (defined by one

7 positive duplicate out of 3 ) or invalid result (defined by a negative signal with the internal

8 control), fresh stools were retested including DNA extraction.

9 Real-time PCR, cytotoxicity assay, culture and identification of the epidemic clone 027/NAP1/BI by PCR-ribotyping were performed respectively by 4 different technicians who

11 were blinded to the results of the other.

\section{Analytical performances}

Detection limit of the multiplex real-time PCR was estimated from ten-fold serial dilutions of purified genomic DNA from strains 027/NAP1/BI (BI 18). Analytical sensitivity of the realtime PCR was assessed by spiking $1 \mathrm{~g}$ of pooled $C$. difficile culture negative-feces with tenfold dilution of different toxigenic strains including CD196, VPI 10463 and ATCC 43598. Sensitivity of the real-time PCR was compared to culture on TCCA (taurocholate, cycloserine, cefoxitin agar) medium. Specificity was evaluated from DNA extracted from different Clostridium spp. other than $C$. difficile including C. bifermentans, C. amygdalinum, C. innocuum, C. ramosum, C. sordellii, C. perfringens, C. tertium, and C. sphenoides.

\section{Cell culture cytotoxicity neutralization assay}

24 The cytotoxicity assay was performed using MRC-5 cells. Fresh stool specimens were diluted in PBS (1:10 [wt/vol]) and centrifuged at 2,500 $\mathrm{g}$ for $30 \mathrm{~min}$. The supernatant was passed 
1 through a $0.45 \mu \mathrm{m}$-pore-size filter and inoculated onto confluent monolayers of MRC-5 cells

2 in $96-$ well microtiter plates that were incubated at $37^{\circ} \mathrm{C}$ in a $6.5 \% \mathrm{CO}_{2}$ atmosphere for $48 \mathrm{~h}$.

3 The final dilution of the fecal filtrate in each well was 1:100. Samples were considered

4 positive if a characteristic cytopathic effect (cell rounding) was observed for at least $50 \%$ of

5 the cells and could be neutralized with anti-Clostridium sordellii antiserum (obtained from M.

6 R. Popoff, National Reference Center for Anaerobes, Institut Pasteur, Paris, France). The in

7 vitro determination of the cytotoxicity of $C$. difficile isolates was performed by inoculating

8 two to five colonies into trypticase yeast broth that was incubated 5 days under anaerobic

9 conditions. The supernatant from this culture was filtered and inoculated on MRC-5 cells as

10 described above. This method is referred as the toxigenic culture.

\section{Direct and enrichment culture}

Direct culture was performed on selective medium TCCA (brain heart infusion agar supplemented with $5 \%$ defibrinated horse blood, $0.1 \%$ taurocholate, $250 \mu \mathrm{g} / \mathrm{ml}$ cycloserine, and $10 \mu \mathrm{g} / \mathrm{ml}$ cefoxitin), and plates were incubated for $48 \mathrm{~h}$ in an anaerobic atmosphere. Presumptive identification was based on colony morphology, typical odor, and Gram staining.

17 Identification was confirmed by use of an enzymatic profile from the RapID32A gallery 18 (bioMérieux, La Balme les Grottes, France).

Stools that were real-time PCR-positive and direct culture-negative were thawed and analyzed using an enrichment procedure. Briefly, stools were inoculated in pre-reduced taurocholate, cycloserine-cefoxitin brain heart infusion broth (TCC broth) and incubated for $48 \mathrm{~h}$ at $37^{\circ} \mathrm{C}$ in an anaerobic atmosphere. Then, $100 \mu \mathrm{l}$ of the broth were subcultured in a second TCC broth, which was incubated for an additional $48 \mathrm{~h}$ in anaerobic atmosphere. Each TCC broth was plated on TCCA agar. Strains were stored at $-80^{\circ} \mathrm{C}$ in one $\mathrm{ml}$ of brain heart infusion broth containing $10 \%$ glycerol. 
2 Identification of the NAP1/027/BI strain.

3 The identification of the 027/NAP1/BI was based both on PCR ribotyping and tcdC

4 sequencing.

5 PCR-ribotyping. PCR ribotyping consists in a comparison of patterns of PCR products of the

$6 \quad$ 16S-23S rRNA intergenic spacer region, as previously described (9). Briefly PCR reactions 7 were performed in a $100 \mu$ l final volume $(50 \mathrm{mM} \mathrm{KCl}, 10 \mathrm{mM}$ Tris- $\mathrm{HCl}(\mathrm{pH} 8.8), 1.5 \mathrm{mM}$ $\mathrm{MgCl}_{2}, 200 \mu \mathrm{M}$ of each dNTP, $100 \mathrm{pmol}$ of each primer, 2.5U of Taq polymerase and $10 \mu \mathrm{l}$ of template DNA). PCR amplifications were performed for 35 cycles of $1 \mathrm{~min}$ at $94^{\circ} \mathrm{C}, 1 \mathrm{~min}$ at $57^{\circ} \mathrm{C}, 2 \mathrm{~min}$ at $72^{\circ} \mathrm{C}$. PCR products were analyzed on a $3 \%$ Resophor agarose gel (BioRad,

11 Ivry, France). An epidemic strain 027/NAP1/BI was used as a control in each run.

12 TcdC sequencing. A 343-bp fragment of the $t c d C$ gene from toxinotype III strains was sequenced on an AB3100 DNA sequencer (Applied Biosystems, Foster City, CA). Briefly, PCR was carried out using the primers tcdC-F: GGGAGATTGTATTATGTTTTCTAAA and tcdC-R: CTTTTTTAGCTTCTTCAGCTT. We purified amplified DNA by enzymatic procedures; $8 \mu \mathrm{l}$ of PCR products were incubated with $2.5 \mathrm{U}$ of exonuclease I (USB Corp., Cleveland, $\mathrm{OH}$ ) and $0.25 \mathrm{U}$ of shrimp alkaline phosphatase (USB Corp., Cleveland, $\mathrm{OH}$ ), with a final volume of $10 \mu \mathrm{l}$, at $37^{\circ} \mathrm{C}$ for 15 min before enzyme inactivation at $80^{\circ} \mathrm{C}$ for 15 min. Then, we added $2 \mu 1$ of BigDye v3.1, $4 \mu 1$ of BigDye v3.1 buffer (Applied Biosystems, Foster City, CA), and $200 \mathrm{nM}$ of primer for a final volume of $20 \mu 1$. The sequencing mixture was denatured at $96^{\circ} \mathrm{C}$ for $1 \mathrm{~min}$, followed by 40 cycles of denaturation at $96^{\circ} \mathrm{C}$ for $30 \mathrm{~s}$, annealing at $56^{\circ} \mathrm{C}$ for $15 \mathrm{~s}$, and extension at $60^{\circ} \mathrm{C}$ for $4 \mathrm{~min}$. Sequences were compiled and analyzed using Gap4 (http: //staden.sourceforge.net/manual/gap4_unix_2.html).

\section{Statistical methods}


1 Sample size : based on an expected sensitivity and specificity of $90 \%$, alpha of $5 \%$ and an

2 expected prevalence of the disease of $15 \%$, we hypothesize that 927 stool specimens should

3 be included to estimate sensitivity and specificity with $5 \%$ of accuracy.

4 Descriptive analysis was performed with SAS V9 system (SAS Institute, Cary, NC, USA).

5 Specificity, sensitivity, negative and positive predictive values and their $95 \%$ confidence

6 intervals $(\mathrm{CI})$ were calculated using $\mathrm{R}$ software version 2.0 ( $\mathrm{R}$ foundation for statistical

7 Computing, Vienna, Austria, www.R-project.org)

8 
2 RESULTS

$4 \quad$ Specificity and analytical sensitivity

5 Sensitivity tests demonstrated that the real-time PCR assay efficiently detected $t c d B$ from all

6 the 67 toxigenic $C$. difficile strains tested. Moreover, deletion at position 117 of the $t c d C$ gene

7 was detected in all the 28 strains from PCR ribotype 027/NAP1/BI and in none of the 40 other

8 strains. Interestingly, 4 strains of toxinotype III with a PCR-ribotyping pattern close but

9 different from 027/NAP1/BI strains by at least one faint band, did not harbour the deletion at

10 position 117 , both by $t c d C$ sequencing and real-time PCR.

11 The threshold detection of the multiplex real-time PCR for $t c d B$ and $t c d C$ was 10 picograms

12 of genomic DNA of 027/NAP1/BI strain.

13 Analytical sensitivity of the multiplex real-time PCR, estimated from spiked fecal specimens

14 with different concentration of the target bacteria, was $10 \mathrm{CFU}$ per $\mathrm{g}$ of stools for $t c d B$, and

$15100 \mathrm{CFU}$ for $t c d \mathrm{C}$.

16 All the 8 Clostridium spp. other than $C$. difficile strains tested including $C$. sordellii, which 17 carries a closely related lethal toxin gene, showed no amplification signal, thereby 18 demonstrating the specificity of the PCR assay.

\section{Clinical performances}

21 The prevalence of positive cytotoxicity assay and toxigenic culture were $6.58 \%(58 / 881)$ and $229.31 \%(82 / 881)$, respectively. The overall agreement between the real-time PCR and the cytotoxicity assay was $95.45 \%$. Using the cytotoxicity assay as a gold standard, the sensitivity, specificity, positive and negative predictive values of real-time PCR were $94.83 \%$ 
1 (95\% CI, 89.13 to $100 \%$ ), $95.5 \%$ (95\% CI, 94.06 to $96.94 \%$ ), $60.44 \%$ (95\% CI, 50.39 to

$270.49 \%$ ) and $99.61 \%$ (95\% CI, 99.18 to 100$)$, respectively.

3 Compared to the toxigenic culture, the sensitivity, specificity, positive and negative predictive

4 values were $86.59 \%, 97.43 \%, 78.02 \%$ and $98.57 \%$ for the real-time PCR and $70.73 \%, 100 \%$,

$5 \quad 100 \%$ and $97.08 \%$ for the cytotoxicity assay (table 2).

6 The cycle threshold for the PCR positive-samples for $t c d B$ ranged from 25 cycles to 39

7 cycles, thereby showing a wide variation in the bacterial load of toxigenic $C$. difficile in feces 8 of patients with CDI.

9 Twenty stool specimens were toxigenic culture-negative and real-time PCR positive. Among 10 them, 14 were thawed and processed to enriched culture in selective broth and $5(35.7 \%)$

11 turned out to be positive for toxigenic C. difficile.

12 Conversely, 11 stool specimens were toxigenic culture-positive and real-time PCR negative. 13 DNA from the corresponding isolates was extracted and used for real-time PCR 14 amplifications and all were positive for $t c d B$.

15 Real-time PCR for detecting $t c d B$ gave indeterminate and invalid results in $10(1.14 \%)$ and 43 $16(4.88 \%)$ cases, respectively. After repeated testing, these figures dropped to $1(0.11 \%)$ and 20 17 (2.27\%), respectively. All these 21 unresolved results were actually negative with the cytotoxicity assay and the toxigenic culture. Two stool specimens (0.2\%) exhibited 19 indeterminate result by the cytotoxicity assay due to a non specific cytotoxic effect leading to 20 a disruption of the cell layer.

21 The epidemic clone 027/NAP1/BI was neither detected by real-time PCR nor by the gold 22 standard assay. However, the five frozen stool specimens from patients infected with the epidemic 027 strains gave a positive result for both $t c d B$ and $t c d C$. 


\section{DISCUSSION}

4 C. difficile infection has become a major nosocomial pathogen in many healthcare facilities

5 including hospitals, long term facilities and nursing homes. Therefore a rapid and accurate

6 diagnosis is crucial for appropriate antibiotic therapy and for the timely implementation of

7 infection control measures, more specially in the context of outbreaks of the hypervirulent 027/NAP1/BI strain.

9 The toxigenic culture is considered as the most sensitive method for the diagnosis of CDI but this method is slow and laborious, often requires $48-72$ hours to complete and therefore is unlikely to be adopted by clinical laboratory as the standard method for $C$. difficile testing. Stool cytotoxicity assay, which has been also considered as a gold standard for a long time, is not standardized, needs cell culture facilities, and results are not obtained before $24-48$ hours. Nowadays, many laboratories routinely use enzyme immunoassay (EIA) for toxin detection. However clinical trials recently demonstrated that EIAs for toxins A and B are not sensitive enough to be used as a stand-alone technique for the diagnosis of CDI $(15,17,32,37,38)$. Moreover, their poor sensitivity often encourages physicians to order additional testing following the first EIA-negative result, if suspicion of CDI remains high (10). However, the gain of repeat testing has been shown to be low $(1,10)$.

To enhance rapidity and sensitivity of CDI diagnosis, experts now recommend to implement a two or three-step algorithm using glutamate dehydrogenase (GDH) detection as a screening method $(14,15)$. This strategy is based on the high negative predictive value of the GDH detection $(33,40,43)$. However this antigen is also found in non-toxigenic $C$. difficile strains and therefore any positive result must be confirmed by a more specific assay detecting toxins. As of today, the choice of confirmation assay is still matter of debates. Some recent clinical 
1 trials reported lower sensitivities (between $70 \%$ and $88 \%$ ) for GDH assays $(17,26)$. Tenover

2 et al. have recently showed that the sensitivity of GDH for the detection of non-027 strains

3 was significantly lower than real-time PCR, suggesting that the variable sensitivities of GDH

4 assays might be explained by the hospital-to-hospital variations of $C$. difficile strains (37).

5 Another study has shown that freezing-thawing of stool sample may also affect GDH

6 detection (34).

7 Another recent option for the diagnosis of CDI is to use real-time PCR. Thus, we developed a real-time PCR assay for the rapid detection of all toxigenic strains from fecal samples and the presumptive identification of the epidemic 027 clone, based on the direct detection of $t c d B$ gene sequence and the single base deletion at nucleotide 117 of the $t c d C$ gene. The analytical sensitivity of this assay was excellent with a detection threshold calculated from spiked fecal samples of $10 \mathrm{UFC} / \mathrm{g}$ of stools for $t c d B$ and $100 \mathrm{UFC} / \mathrm{g}$ stools for $t c d C$. This detection limit is much lower that those previously reported by Belanger et al. $\left(5.10^{4} \mathrm{CFU} / \mathrm{g}\right.$ of stools) or van den Berg $\left(10^{5} \mathrm{CFU} / \mathrm{g}\right.$ of stools $)(8,41)$.

To date, four different amplification assays have been recently cleared by the FDA for laboratory use in the US. These assays target $t c d B$ (ProGastro Cd, Prodesse; BD GeneOhm $C$. diff, BD Diagnostics), tcdA (Illumigene Meridian) or $t c d B$ in combination with binary toxin and deletion of $t c d C$ (Xpert $C$. difficile, Cepheid). These assays have been compared to toxigenic culture in several clinical trials. A review of clinical performances indicated that their sensitivity and specificity range from $77.3 \%$ to $97.1 \%$ and $93 \%$ to $100 \%$, respectively (table 3) $(4,17,22,25,31,35-38)$. The performance characteristics of our in-house real-time PCR assay are in agreement with those data, with a sensitivity and a specificity of 86.6 and $97.4 \%$, respectively. It performs better than the cytotoxicity assay when using the toxigenic culture as the gold standard method. 
1 Among the 20 specimens that were PCR-positive but toxigenic culture-negative, 14 were

2 cultured using an enrichment method. Interestingly, among these, 5 (35.7\%) appeared to be 3 true positive by enriched toxigenic culture. The corrected sensitivity and specificity of the

4 real-time PCR would be $87.3 \%$ and $98.05 \%$, respectively. The reasons why direct toxigenic

5 culture appeared negative could include a low concentration of microorganisms in very

6 heterogeneous sample or a growth inhibition due to previous therapy for C. difficile.

7

The hands-on technologist time of our real-time PCR is about approximately $30 \mathrm{~min}$., which is similar to other types of detection assays used for C. difficile (cytotoxicity assay, EIA). To date, the only test that showed a significant shorter hands-on-time is the Gene Xpert $C$. diff (Cepheid) where DNA extraction and PCR reaction are fully automated and performed in the same cartridge $(22,37)$. Another main advantage of real-time PCR is the rapid turn-around time. Specimen processing, miniMag extraction and testing by the real-time PCR took approximately 3 hours before the results were reported. This time is considerably shorter than the 24-48h for the cytotoxicity assay and much shorter than the 3-5 days for the toxigenic culture.

The real-time PCR assay we developed may rise several questions.

First, there is a practical concern regarding the clinical specificity of this assay. Actually, realtime PCR is able to detect toxin genes but not the toxin itself. Because asymptomatic carriage of toxigenic strains is proportional to the length of stay and may reach $50 \%$ after 4 weeks of hospitalization (12), the clinical significance of toxigenic strain remains uncertain. However, whereas it is true that the isolation of a toxigenic strain of $C$. difficile does not prove that the patient is infected, it is also true that it is the most likely cause of the diarrhea $(16,21)$. The risk of real-time PCR as well as toxigenic culture is to treat by excess patients who are simply 
1 colonized by a toxin producing strain. Microbiologists should be aware of this limitation

2 when interpreting the result.

3 The second limitation is the potential genetic change in $t c d B$ gene or the emergence of $t c d A^{+}$

$4 t c d B^{-}$strains, resulting in false negative results. To date, these trends are still hypothetical and

5 the emergence of new genotypes affecting clinical performances of real-time PCR for $t c d B$

6 remains undocumented. Nevertheless, it will be important to periodically monitor the

7 emergence of new genotypes, which could negatively impact performances of $t c d B$-based assays. During the development of our real-time PCR, we have tested our primers and probes on 68 strains including the most common toxinotypes and all were positive. Moreover, strains isolated from toxigenic culture-positive and real-time PCR-negative stools, tested positive when DNA from these strains was used as template for PCR, suggesting that false negative results were not associated with a mismatch of primers and/or probes. The third limitation of our real time PCR assay is the high rate $(6.01 \%)$ of unresolved results upon initial testing, mainly due to a negative result for the internal control. That might be explained either by an inhibition of PCR reaction or by DNA extraction failure. The rate dropped to $2.38 \%$ after repeated testing. A review of the recent literature indicated that the rate of unresolved results with other commercially available real-time PCR are similar and range from $0 \%$ to $3.3 \%$. However, it should be emphasized that some PCR-based methods commercially available do not have an internal control for DNA extraction (BD GeneOhm $C$. diff), and therefore cannot delineate true negative result from DNA extraction failure.

During the clinical trial, the epidemic 027/NAP1/BI strain was not detected. This result is in agreement with a recent national survey of $C$. difficile infection where 027 represented only $3.6 \%(8 / 224)$ of all isolates (Eckert C. et al., 50 ${ }^{\text {th }}$ ICAAC, Boston, 12-15 September 2010). As a consequence, the sensitivity of our real-time PCR for the identification of the 027/NAP1/BI 
1 strain could not be calculated. Nevertheless no false positive result in $t c d C$ was observed, 2 suggesting that the specificity of the real-time PCR for $t c d C$ deletion was $100 \%$. It also

3 suggests that the deletion at nt 117 is not found in other strains of $C$. difficile and remains

4 specific of the epidemic 027/NAP1/BI strain. To overcome the lack of 027/NAP1/BI strains

5 in our population, the real-time PCR was performed from 5 frozen stools of patients infected

6 by the $027 / \mathrm{NAP} 1 / \mathrm{BI}$ and all were positive both for $t c d B$ and $t c d C$. Among the commercial

7 multiplex real-time PCR assays, only the Xpert $C$. difficile (Cepheid) is able to detect the 8 presumptive PCR-ribotype 027 strain with a sensitivity and specificity of 100 and $98.1 \%$, 9 respectively (22).

In summary, our data suggest that sensitivity and specificity of our real-time PCR are comparable to those of commercially available real-time PCR. The rapid turn-around time of real-time PCR would allow laboratories to speed up the detection of toxigenic strains and consequently to improve management of patients with CDI. However, the savings realized with a rapid and accurate diagnostic method should be further evaluated.

\section{Acknowledgements}

This study was supported by a grant from the Programme Hospitalier de Recherche Clinique (AOR06006). The authors are grateful to Guillaume Arlet, Vincent Jarlier and Alexandra Aubry for providing stool specimens from patients suspected of having CDI and Jean Pierre 
References

1. Aichinger, E., C. D. Schleck, W. S. Harmsen, L. M. Nyre, and R. Patel. 2008. Nonutility of repeat laboratory testing for detection of Clostridium difficile by use of PCR or enzyme immunoassay. J Clin Microbiol 46:3795-7.

2. Akerlund, T., I. Persson, M. Unemo, T. Noren, B. Svenungsson, M. Wullt, and L. G. Burman. 2008. Increased sporulation rate of epidemic Clostridium difficile Type 027/NAP1. J Clin Microbiol 46:1530-3.

3. Archibald, L. K., S. N. Banerjee, and W. R. Jarvis. 2004. Secular trends in hospital-acquired Clostridium difficile disease in the United States, 1987-2001. J Infect Dis 189: 1585-9.

4. Barbut, F., M. Braun, B. Burghoffer, V. Lalande, and C. Eckert. 2009. Rapid detection of toxigenic strains of Clostridium difficile in diarrheal stools by real-time PCR. J Clin Microbiol 47:1276-7.

5. Barbut, F., M. Delmee, J. S. Brazier, J. C. Petit, I. R. Poxton, M. Rupnik, V. Lalande, C. Schneider, P. Mastrantonio, R. Alonso, E. Kuipjer, and M. Tvede. 2003. A European survey of diagnostic methods and testing protocols for Clostridium difficile. Clin Microbiol Infect 9:989-96.

6. Barbut, F., P. Mastrantonio, M. Delmee, J. Brazier, E. Kuijper, and I. Poxton. 2007. Prospective study of Clostridium difficile infections in Europe with phenotypic and genotypic characterisation of the isolates. Clin Microbiol Infect 13:1048-57.

7. Bartlett, J. G. 2008. Historical perspectives on studies of Clostridium difficile and C. difficile infection. Clin Infect Dis 46 Suppl 1:S4-11.

8. Belanger, S. D., M. Boissinot, N. Clairoux, F. J. Picard, and M. G. Bergeron. 2003. Rapid detection of Clostridium difficile in feces by real-time PCR. J Clin Microbiol 41:730-4.

9. Bidet, P., F. Barbut, V. Lalande, B. Burghoffer, and J. C. Petit. 1999. Development of a new PCR-ribotyping method for Clostridium difficile based on ribosomal RNA gene sequencing. FEMS Microbiol Lett 175:261-6.

10. Cardona, D. M., and K. H. Rand. 2008. Evaluation of repeat Clostridium difficile enzyme immunoassay testing. J Clin Microbiol 46:3686-9.

11. Chang, T. W., S. L. Gorbach, and J. B. Bartlett. 1978. Neutralization of Clostridium difficile toxin by Clostridium sordellii antitoxins. Infect Immun 22:41822.

12. Clabots, C. R., S. Johnson, M. M. Olson, L. R. Peterson, and D. N. Gerding. 1992. Acquisition of Clostridium difficile by hospitalized patients: evidence for colonized new admissions as a source of infection. J Infect Dis 166:561-7.

13. Cohen, M. B. 2009. Clostridium difficile infections: emerging epidemiology and new treatments. J Pediatr Gastroenterol Nutr 48 Suppl 2:S63-5.

14. Cohen, S. H., D. N. Gerding, S. Johnson, C. P. Kelly, V. G. Loo, L. C. McDonald, J. Pepin, and M. H. Wilcox. 2010. Clinical practice guidelines for Clostridium difficile infection in adults: 2010 update by the society for healthcare epidemiology of America (SHEA) and the infectious diseases society of America (IDSA). Infect Control Hosp Epidemiol 31:431-55.

15. Crobach, M. J., O. M. Dekkers, M. H. Wilcox, and E. J. Kuijper. 2009. European Society of Clinical Microbiology and Infectious Diseases (ESCMID): data review and 
recommendations for diagnosing Clostridium difficile-infection (CDI). Clin Microbiol Infect 15:1053-66.

16. Delmee, M., J. Van Broeck, A. Simon, M. Janssens, and V. Avesani. 2005. Laboratory diagnosis of Clostridium difficile-associated diarrhoea: a plea for culture. J Med Microbiol 54:187-91.

17. Eastwood, K., P. Else, A. Charlett, and M. Wilcox. 2009. Comparison of nine commercially available Clostridium difficile toxin detection assays, a real-time PCR assay for $\mathrm{C}$. difficile tcdB, and a glutamate dehydrogenase detection assay to cytotoxin testing and cytotoxigenic culture methods. J Clin Microbiol 47:3211-7.

18. Freeman, J., M. P. Bauer, S. D. Baines, J. Corver, W. N. Fawley, B. Goorhuis, E. J. Kuijper, and M. H. Wilcox. 2010. The changing epidemiology of Clostridium difficile infections. Clin Microbiol Rev 23:529-49.

19. Frigui, W., D. Bottai, L. Majlessi, M. Monot, E. Josselin, P. Brodin, T. Garnier, B. Gicquel, C. Martin, C. Leclerc, S. T. Cole, and R. Brosch. 2008. Control of M. tuberculosis ESAT-6 secretion and specific T cell recognition by PhoP. PLoS Pathog 4:e33.

20. Gerding, D. N. 2009. Clostridium difficile 30 years on: what has, or has not, changed and why? Int J Antimicrob Agents 33 Suppl 1:S2-8.

21. Gerding, D. N., M. M. Olson, L. R. Peterson, D. G. Teasley, R. L. Gebhard, M. L. Schwartz, and J. T. Lee, Jr. 1986. Clostridium difficile-associated diarrhea and colitis in adults. A prospective case-controlled epidemiologic study. Arch Intern Med 146:95-100.

22. Huang, H., A. Weintraub, H. Fang, and C. E. Nord. 2009. Comparison of a commercial multiplex real-time PCR to the cell cytotoxicity neutralization assay for diagnosis of Clostridium difficile infections. J Clin Microbiol 47:3729-31.

23. Kelly, C. P., and J. T. LaMont. 2008. Clostridium difficile--more difficult than ever. N Engl J Med 359:1932-40.

24. Kuijper, E. J., F. Barbut, J. S. Brazier, N. Kleinkauf, T. Eckmanns, M. L. Lambert, D. Drudy, F. Fitzpatrick, C. Wiuff, D. J. Brown, J. E. Coia, H. Pituch, P. Reichert, J. Even, J. Mossong, A. F. Widmer, K. E. Olsen, F. Allerberger, D. W. Notermans, M. Delmee, B. Coignard, M. Wilcox, B. Patel, R. Frei, E. Nagy, E. Bouza, M. Marin, T. Akerlund, A. Virolainen-Julkunen, O. Lyytikainen, S. Kotila, A. Ingebretsen, B. Smyth, P. Rooney, I. R. Poxton, and D. L. Monnet. 2008. Update of Clostridium difficile infection due to PCR ribotype 027 in Europe, 2008. Euro Surveill 13.

25. Kvach, E. J., D. Ferguson, P. F. Riska, and M. L. Landry. 2010. Comparison of BD GeneOhm Cdiff real-time PCR assay with a two-step algorithm and a toxin A/B enzyme-linked immunosorbent assay for diagnosis of toxigenic Clostridium difficile infection. J Clin Microbiol 48:109-14.

26. Larson, A. M., A. M. Fung, and F. C. Fang. 2010. Evaluation of tcdB real-time PCR in a three-step diagnostic algorithm for detection of toxigenic Clostridium difficile. $\mathbf{J}$ Clin Microbiol 48:124-30.

27. Matamouros, S., P. England, and B. Dupuy. 2007. Clostridium difficile toxin expression is inhibited by the novel regulator TcdC. Mol Microbiol 64:1274-88.

28. McDonald, L. C., G. E. Killgore, A. Thompson, R. C. Owens, Jr., S. V. Kazakova, S. P. Sambol, S. Johnson, and D. N. Gerding. 2005. An Epidemic, Toxin GeneVariant Strain of Clostridium difficile. N Engl J Med 353:2433-41.

29. Merrigan, M., A. Venugopal, M. Mallozzi, B. Roxas, V. K. Viswanathan, S. Johnson, D. N. Gerding, and G. Vedantam. 2010. Human Hypervirulent 
Clostridium difficile Strains Exhibit Increased Sporulation as well as Robust Toxin Production. J Bacteriol. Ahead of printing

30. Muto, C. A., M. Pokrywka, K. Shutt, A. B. Mendelsohn, K. Nouri, K. Posey, T. Roberts, K. Croyle, S. Krystofiak, S. Patel-Brown, A. W. Pasculle, D. L. Paterson, M. Saul, and L. H. Harrison. 2005. A large outbreak of Clostridium difficile-associated disease with an unexpected proportion of deaths and colectomies at a teaching hospital following increased fluoroquinolone use. Infect Control Hosp Epidemiol 26:273-80.

31. Novak-Weekley, S. M., E. M. Marlowe, J. M. Miller, J. Cumpio, J. H. Nomura, P. H. Vance, and A. Weissfeld. 2010. Clostridium difficile testing in the clinical laboratory by use of multiple testing algorithms. J Clin Microbiol 48:889-93.

32. Planche, T., A. Aghaizu, R. Holliman, P. Riley, J. Poloniecki, A. Breathnach, and S. Krishna. 2008. Diagnosis of Clostridium difficile infection by toxin detection kits: a systematic review. Lancet Infect Dis 8:777-84.

33. Reller, M. E., C. A. Lema, T. M. Perl, M. Cai, T. L. Ross, K. A. Speck, and K. C. Carroll. 2007. Yield of stool culture with isolate toxin testing versus a two-step algorithm including stool toxin testing for detection of toxigenic Clostridium difficile. J Clin Microbiol 45:3601-5.

34. Sharp, S. E., L. O. Ruden, J. C. Pohl, P. A. Hatcher, L. M. Jayne, and W. M. Ivie. 2010. Evaluation of the C.Diff Quik Chek Complete Assay, a new glutamate dehydrogenase and A/B toxin combination lateral flow assay for use in rapid, simple diagnosis of Clostridium difficile disease. J Clin Microbiol 48:2082-6.

35. Stamper, P. D., R. Alcabasa, D. Aird, W. Babiker, J. Wehrlin, I. Ikpeama, and K. C. Carroll. 2009. Comparison of a commercial real-time PCR assay for tcdB detection to a cell culture cytotoxicity assay and toxigenic culture for direct detection of toxin-producing Clostridium difficile in clinical samples. J Clin Microbiol 47:3738.

36. Stamper, P. D., W. Babiker, R. Alcabasa, D. Aird, J. Wehrlin, I. Ikpeama, L. Gluck, and K. C. Carroll. 2009. Evaluation of a new commercial TaqMan PCR assay for direct detection of the Clostridium difficile toxin B gene in clinical stool specimens. J Clin Microbiol 47:3846-50.

37. Tenover, F. C., S. Novak-Weekley, C. W. Woods, L. R. Peterson, T. Davis, P. Schreckenberger, F. C. Fang, A. Dascal, D. N. Gerding, J. H. Nomura, R. V. Goering, T. Akerlund, A. S. Weissfeld, E. J. Baron, E. Wong, E. M. Marlowe, J. Whitmore, and D. H. Persing. 2010. Impact of Strain Types on Detection of Toxigenic Clostridium difficile: Comparison of Molecular Diagnostic and Enzyme Immunoassay Approaches. J Clin Microbiol. Ahead of printing

38. Terhes, G., E. Urban, J. Soki, E. Nacsa, and E. Nagy. 2009. Comparison of a rapid molecular method, the BD GeneOhm Cdiff assay, to the most frequently used laboratory tests for detection of toxin-producing Clostridium difficile in diarrheal feces. J Clin Microbiol 47:3478-81.

39. Terhes, G., E. Urban, J. Soki, L. Szikra, M. Konkoly-Thege, M. Vollain, and E. Nagy. 2009. Assessment of changes in the epidemiology of Clostridium difficile isolated from diarrheal patients in Hungary. Anaerobe 15:237-40.

40. Ticehurst, J. R., D. Z. Aird, L. M. Dam, A. P. Borek, J. T. Hargrove, and K. C. Carroll. 2006. Effective detection of toxigenic Clostridium difficile by a two-step algorithm including tests for antigen and cytotoxin. J Clin Microbiol 44:1145-9.

41. van den Berg, R. J., E. J. Kuijper, L. E. van Coppenraet, and E. C. Claas. 2006. Rapid diagnosis of toxinogenic Clostridium difficile in faecal samples with internally controlled real-time PCR. Clin Microbiol Infect 12:184-6. 
42. Warny, M., J. Pepin, A. Fang, G. Killgore, A. Thompson, J. Brazier, E. Frost, and L. C. McDonald. 2005. Toxin production by an emerging strain of Clostridium difficile associated with outbreaks of severe disease in North America and Europe. Lancet 366:1079-84.

43. Wolfhagen, M. J., K. Meijer, A. C. Fluit, R. Torensma, R. A. Bruinsma, A. Fleer, and J. Verhoef. 1994. Clinical significance of Clostridium difficile and its toxins in faeces of immunocompromised children. Gut 35:1608-12. 
1 TABLE 1: Primers and probes used in the PCR assays.

2

\begin{tabular}{ccccc}
\hline Target & Efficiency* & Length & Primer and & Sequences \\
& & & probe & \\
\hline Rv3865 & $1,74-1,90$ & $65 \mathrm{bp}$ & Forward & CGAGTTCAGCTTACCCATGGTT \\
& & & Reverse & CAAACTCTTGCAGCGTGTCATT \\
& & & Probe & TTCACGTCGAAATT-NED* \\
\hline$t c d B$ & $1,63-1,88$ & $197 \mathrm{bp}$ & Forward & ATGCAGCCAAAGTTGTTGAA \\
& & & Reverse & CTGCCATTATACCTATCTTAGCTTC \\
& & & Probe & AGTGACCCATTATT-VIC* \\
& & & Forward & GAAATGACCTCCTCATGGTCT \\
& & & Reverse & AGTAATGAAAGAAAAGGAAGCTCT
\end{tabular}

AA

Probe ACACACCAAAATA-FAM*

3 "Triplex oligos efficiency depends on the number (3-1) of targets amplified. pour coller avec le sens

4 des efficacités, ex Rv3865: 1,74 pour triplex (3) et 1,90 pour simplex (1)

5

6 
TABLE 2 : Performances of cytotoxicity assay and real-time PCR for the detection of toxigenic strains of $C$. difficile.

\begin{tabular}{|c|c|c|c|c|c|c|}
\hline \multirow[t]{3}{*}{ Assay } & \multicolumn{2}{|c|}{ Toxigenic culture } & \multicolumn{4}{|c|}{ Assay performance (95\% confidence interval) } \\
\hline & \multirow[b]{2}{*}{ Negative } & \multirow[b]{2}{*}{ Positive } & \multirow{2}{*}{$\begin{array}{l}\text { Sensitivity } \\
(\%)\end{array}$} & \multirow{2}{*}{$\begin{array}{c}\text { Specificity } \\
(\%)\end{array}$} & \multirow{2}{*}{$\begin{array}{l}\text { PPV } \\
(\%)\end{array}$} & \multirow{2}{*}{$\begin{array}{l}\text { NPV } \\
(\%)\end{array}$} \\
\hline & & & & & & \\
\hline \multicolumn{7}{|l|}{ Cytotoxicity assay } \\
\hline Negative & 797 & 24 & 70.7 & 100 & 100 & 97.08 \\
\hline Positive & 0 & 58 & $(60.88-80.58)$ & & $(95.91-98.25)$ & $(96.19-98.35)$ \\
\hline Total & 797 & 82 & & & & \\
\hline \multicolumn{7}{|l|}{ Real-Time PCR } \\
\hline Negative & 758 & 11 & 86.59 & 97.43 & 78.02 & 98.57 \\
\hline Positive & 20 & 71 & (79.21-93.97) & $(96.32-98.54)$ & $(69.51-86.53)$ & (97.74-99.4) \\
\hline Total & 778 & 82 & & & & \\
\hline
\end{tabular}


TABLE 3 : Comparison of commercially real-time PCR performances for the detection of toxigenic strains of C. difficile.

\begin{tabular}{|c|c|c|c|c|c|c|c|c|}
\hline Authors (year) & Assay & Target & $\begin{array}{c}\text { No } \\
\text { samples }\end{array}$ & $\begin{array}{c}\text { Sensitivity } \\
(\%)\end{array}$ & $\begin{array}{l}\text { Specificity } \\
(\%)\end{array}$ & Gold standard & $\begin{array}{c}\text { Indet. } \\
(\%)\end{array}$ & $\begin{array}{c}\text { Preval. } \\
(\%)\end{array}$ \\
\hline Barbut F. (2009) & \multirow{5}{*}{$\begin{array}{l}\text { BD GeneOhm } \\
\text { C. diff assay }\end{array}$} & \multirow{5}{*}{$t c d B$} & 300 & 93.9 & 97.7 & $\mathrm{TC}$ & 3.3 & 11 \\
\hline Stamper P. (2009) & & & 404 & 83.6 & 98.2 & $\mathrm{TC}$ & 0.5 & 15.2 \\
\hline Kvach E. (2010) & & & 400 & 91.4 & 100 & $\mathrm{TC}$ & 0 & 26.2 \\
\hline Terhes G. (2009) & & & 600 & 96.4 & 99.1 & $\begin{array}{c}\text { CTA } \\
\text { (+TC for } \\
\text { discrepant results) }\end{array}$ & 0 & 9.2 \\
\hline Eastwood K. (2010) & & & 558 & 88,5 & 95.4 & TC & 1.1 & 18.6 \\
\hline Huang H. (2009) & \multirow{3}{*}{$\begin{array}{c}\text { Cepheid } \\
\text { Xpert } C . \text { diff. }\end{array}$} & \multirow{3}{*}{$\begin{array}{c}t c d B \\
t c d C \\
\text { binary toxin } \\
\text { gene }\end{array}$} & 220 & 97.1 & 93 & $\begin{array}{c}\text { CTA } \\
\text { (+ TC for } \\
\text { discrepant results) }\end{array}$ & 0 & 9.2 \\
\hline Tenover F. (2010) & & & $\begin{array}{c}2296 \\
\text { (multicenter) }\end{array}$ & 93.5 & 94 & Enriched TC & 0.4 & 14.7 \\
\hline Novak-Weekley S. (2010) & & & 432 & 94.4 & 96.3 & $\mathrm{TC}$ & 0.9 & 19.6 \\
\hline Stamper P. (2009) & $\begin{array}{l}\text { ProGastro Cd assay } \\
\text { (Prodesse) }\end{array}$ & $t c d B$ & 285 & 77.3 & 99.2 & $\mathrm{TC}$ & 1.4 & 15.7 \\
\hline This study & & $\begin{array}{l}t c d B \\
t c d C\end{array}$ & 881 & 86.6 & 97.4 & $\mathrm{TC}$ & 2.4 & 9.3 \\
\hline
\end{tabular}


TC: toxigenic culture ; CTA: stool cytotoxicity assay ; Indet.: indeterminate results; Preval.: prevalence 